\title{
Developing a Multidisciplinary Tourism Planning Approach on Cultural Routes
}

\author{
Beste Sabır*
}

\author{
Keywords: \\ Cultivated Tourist \\ Cultural Routes \\ Rural Tourism \\ Tourism Planning \\ Tranquil Development
}

Article History:

Submitted:22.03.2019

Accepted:20.07.2019

\begin{abstract}
Essence of the cultural routes can be described as a flow in the space where the cultivated tourists rediscover a slow lifestyle, meet with the local area in many ways -multi layers of the area unfolds to the tourists, they exchange knowledge with the local environment, learn about the area also they leave behind a knowledge too - to the local habitants of the place. This is a double-sided exchange. Thus, the settlements overlapping with the cultural routes need to be approached and planned with a special touch and awareness -related with the local data. Therefore, a multidisciplinary approach is needed. Paper examines specific points related to this unfolding process such as: Essence of the walking; experiencing the nature; respecting culture and history. Three routes will be examined and interrelated for the "good practice" and learn from the others in order to reach sustainable and multidisciplinary planning insights.
\end{abstract}

\section{Doi: http://dx.doi.org/10.31822/jomat.543891}

\section{Introduction}

Cultural tourism is defined by the World Tourism Organization (Report WTO, 2012) as "trips, whose main or concomitant goal is visiting the sites and events whose cultural and historical value has turn them being a part of the cultural heritage of a community". In this kind of tourism, there is a notion of cultivated tourists that they are searching for a specific essence in the environment where they visit. Ecology, nature, architecture, history and agriculture is included in this kind of tourism and it has a relation with the environment and local atmosphere. In mass tourism and sea, sand, sun tourism types we face with major problems such as; rejection of the local atmosphere, not supporting the local economy, not unique and similar atmospheres, not having sustainable mentality etc. Culture of the area is the biggest input in this kind of tourism. With the globalization and common consumption models, many locations are becoming similar with each other, wherever we go, we face with the same elements in the environment. Thus, touristic places standardized and cannot give something different and related to the place anymore. But the cultural tourists seek for the unique and interesting places for to meet with the new worlds. Therefore, locality becomes crucial and after realizing this point, many touristic locations and governments started to market their places with the local products, history and specialties that they have. It will be beneficial to argues what is culture and cultural tourism and cultural routes to have a deeper understanding for to be able to criticize the conventional tourism planning approaches and open up for the new models for tourism planning such as a multidisciplinary approach.

\subsection{The Term of "Culture" and "Cultural Tourism"}

"Culture is that complex whole which includes knowledge, belief, art, morals, law, custom, and any other capabilities and habits acquired by man as a member of society" (Tylor, 1871). Culture is 
not a stable and constant concept; throughout the history we interpret that many cultures have been interacted with each other and effected and evolved by these interchanges. By ancient trading system, many cultures blended with each other, after the tourism and movement of the tourists around the world, this blending and interchanging process continued. Therefore, development of cultural tourism should determine and support these cultural exchanges. Roshan Cultural Heritage Institute states that; "Culture refers to the following ways of life, including but not limited to:

- Language: the oldest human institution and the most sophisticated medium of expression.

- Arts \& Sciences: the most advanced and refined forms of human expression.

- Thought: the ways in which people perceive, interpret, and understand the world around them.

- Spirituality: the value system transmitted through generations for the inner well-being of human beings, expressed through language and actions.

- Social activity: the shared pursuits within a cultural community, demonstrated in a variety of festivities and life-celebrating events.

- Interaction: the social aspects of human contact, including the give-and-take of socialization, negotiation, protocol, and conventions". institute.org/474551)

Within the cultural tourism market, several different demand segments can be identified. In broad terms, the main segments tend to relate to people who have either a general interest in culture, and who see culture as just one aspect of the destination, and those with a specific interest in culture, for who culture is the main reason for travelling to the destination. Paschinger (2007) combines the ATLAS distinction between 'specific' and 'general' cultural tourism with the work of McKercher and Du Cros (2002) to explain the cultural tourism market in Image 1.

"The purposeful cultural tourist, comparable to the "specific" cultural tourist introduced by Richards (1996, p. 34), is entirely motivated by culture in visiting a certain destination or cultural attraction and engages in a deep experience. The sightseeing cultural tourist is chiefly motivated for cultural reasons; too, however this experience remains shallow. The serendipitous cultural tourist does not plan to travel for cultural motives, but after participating still ends up having a deep cultural experience. The casual cultural tourist offers only a weak motive for visiting a certain cultural attraction or destination, and as a result, this experience remains shallow. Finally, the incidental cultural tourist does not travel for cultural tourism reasons at all, and when they find themselves engaged in some sort of cultural activities, those typically remain shallow."

This notion of being shallow can explain more the definition of cultivated tourists and their experience in ironical way. Contrary to the shallow experiences, cultivated tourists expect to be deepen, resolve and get connected with the area that they are in.

\subsection{Definition of Cultivated Tourist}

After defining the culture and cultural tourism process, it is also important to define and underline essence of the cultivated tourist. Cultural tourist does not travel with the aim of

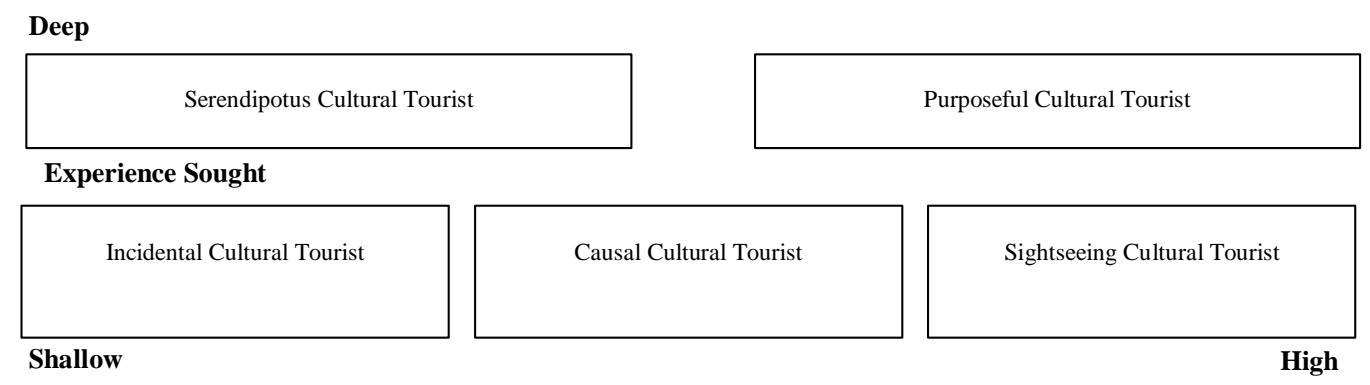

Image 1. Importance of Cultural Tourism in the decision to visit destination 


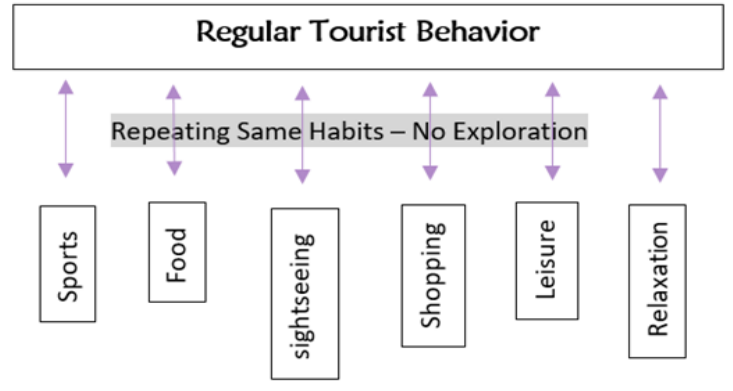

Image 2. Expressing the regular tourist search during the holiday process. Source: Author

repeating the same habits that they have on their daily life, instead they travel and move for to be able to meet with different culture, heritage and history. The cultural tourist becomes to have a cultivated feature, that has the motivation to search for and meet with the different values around the world and re-discover a slow lifestyle. Thus, it is crucial to remember the behaviours and expectations of cultivated tourists during the planning process of cultural routes. Image 2 shows that; regular tourists choose usually to repeat the habits and actions with their daily life while they are on holidays. Image $\mathbf{3}$ defines the cultivated tourist characteristics and behaviors during their holiday.

\subsection{Cultural Routes}

ICOMOS (International Scientific Committee on Cultural Tourism) made one of the most detailed definitions: "Cultural tourism can be defined as that activity which enables people to experience the different ways of life of other people, thereby gaining at first hand an understanding of their customs, traditions, the physical environment, the intellectual ideas and those places of architectural, historic, archaeological or other cultural significance which remain from earlier times. Cultural tourism differs from recreational tourism in that it seeks to gain an understanding or appreciation of the nature of the place being visited." (ICOMOS Charter for Cultural Tourism, Draft April 1997). This explanation of cultural tourism gives insight about the cultural routes as well. Therefore, on the cultural routes, the tourists meet with this knowledge in an active way; mostly by walking or climbing. Briefly, it is an educational experience.

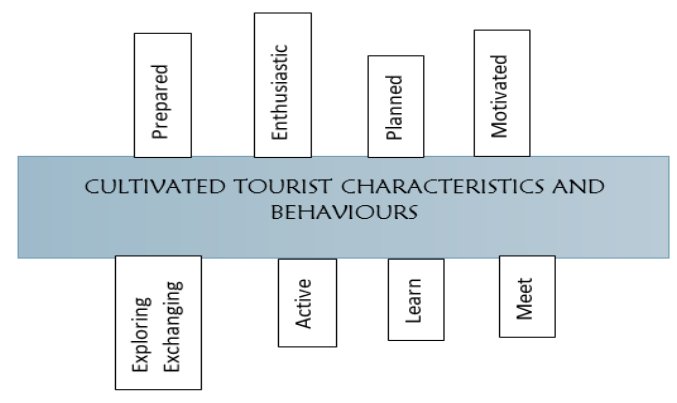

Image 3. Defining the cultivated tourist characteristics and behaviors during their holiday. Source: Author

When the cultivated tourists experience the cultural routes by walking, they have chance to meet with culture, history, nature, gastronomy, vernacular atmosphere, spiritual knowledge depending on the characteristics of the area. Image 4 sums up this flow. Cultural routes may include many points of cultural tourism, but this is an active type of tourism. Essence of walking, moving, seeing directs this process and there is a flow always in the process as well. Also, in this kind of tourism they prefer unspoiled natural landscapes. They want to discover as well. Briefly, cultural routes are about journeys where the tourists go into a process of discovery, mindful/aware, self-realization with the flow/movements in the area.

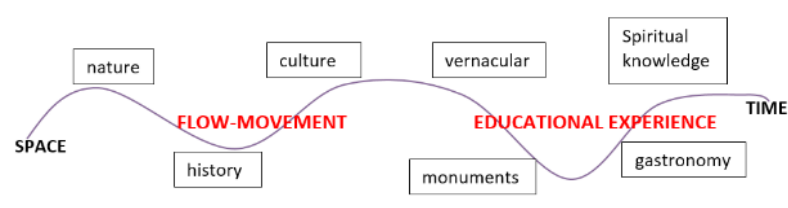

Image 4. Process of Cultural Routes. Source: Author

\subsection{Characteristics of Cultural Routes}

Cultural routes may include wide range of interests such as; gastronomy, arts, linguistics, architecture, spirituality, religion, sports etc. "Thematic routes are such tourism products which row up natural or manmade attractions accessible by different transport forms around a chosen topic or theme" (Puczkó \& Rátz, 2000; 2007). Thematic routes around the world increased in the last years. This paper aims to focus on to the natural cultural routes which are mostly visited and passed by walking and with very small scaled transportation styles and vehicles. 
"On the successful operation of the thematic routes we find numerous successful methods and examples in and outside Europe. Forming an international co-operation may have number of advantages but challenges as well to the participants. The creation of the route is seemingly an easy task, so the attractions must be selected and developed adequate to the main theme and applying management methods as well. It can be referred to the positive effects that considering costs these supplies are created with a small range of investment, they be diverse both spatially and timely, can contribute to the unutilized tourism resources and can captivate a new demand group for the cultural and heritage tourism. We keep count on the benefits side of thematic route creation that:

- They can be realized with a relatively small investment,

- They can diverse the tourism demand both timely and spatially,

- They can utilize unexploited resources,

- A new demand group can be captivated to the given attraction.

- Apart from the above mentioned we may interpret as an additional positive economic effect the motivation of the enterprises among residents,

- Support of investments, and development concerning buildings, infrastructure and human resources,

- The settling down of related services, which can also be used by the residents, (Image 5, 6)

- The effect of the income increases due to the increasing tourism flow, and as a result of the mentioned workplace creation" (Berki \& Csapó, 2008).

$\bullet$

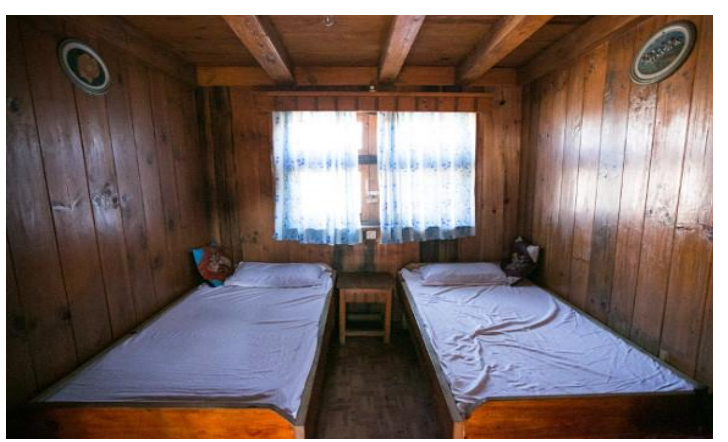

Image 5. https://www.mountainiq.com/nepal-teahouses/, Basic room of an accommodation unit-lodge in Nepal.
The most important segment of thematic routes is the cultural routes especially in Europe. "The first cultural routes were introduced by the Council of Europe in 1987. This cooperation of the Council started first with ten cultural routes marking the stages in Europe's development, realizing that Europe's cultural routes cross over and link the local, the regional and the international level as well. This co-operation for today is one of the most well-known and well practicing in Europe. As a result of the experienced fast development in 1998 the Council of Europe wanted to set the project within a more formal co-operation framework by establishing certain regulations and so created the Atlas of Cultural Routes. These regulations established a reformed network of cultural routes called European Institute of Cultural Routes" (Berki \& Csapó, 2008). There are important routes around Europe such as; Via Francigena, Federation of the Clunisian sites in Europe, The Way of St. James (Camino de Santiago), Klösterreich, Himalayan Trek in Nepal and India. Also, important routes exist in Turkey, such as Lycian Route, Carian Way, St. Paul's Way.

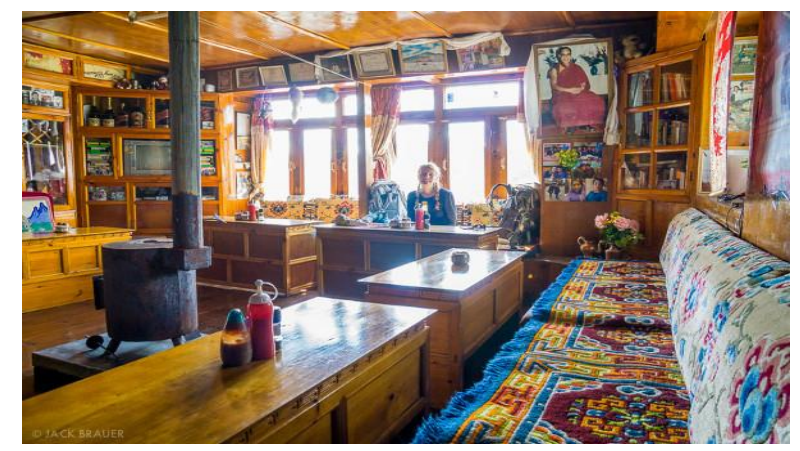

Image 6. https://www.mountainiq.com/nepal-tea-houses/ , Tea houses

\subsection{Comparison of Annapurna Circuit, Lycian} and Carian Routes: A Personal Experience

In this section three examples from the world will be examined depending on personal experiences and literature reviews. It is aimed to examine these three routes in several perspectives to gain more knowledge and be able to deepen in multidisciplinary process of tourism planning in these cultural routes. Table 1 compares these three routes. 
Table 1. Comparison of three cultural routes

\begin{tabular}{|c|c|c|c|}
\hline & $\begin{array}{l}\text { Annapurna Base Camp Trek / Himalayans, } \\
\text { Nepal }\end{array}$ & Lycian Way / Turkey & Carian Way /Turkey \\
\hline Year/ Age & $\begin{array}{l}\text { Established in } 1986 \text { as Annapurna } \\
\text { Conservation Area Project (ACAP) }\end{array}$ & Opened in 1999 & 2013 \\
\hline Distance and time & $\begin{array}{l}7 \text { to } 12 \text { days, } 160-230 \mathrm{~km} \text { (multi choices for to } \\
\text { shorten and adjust the track) }\end{array}$ & 21 days, $535 \mathrm{~km}$. & $800 \mathrm{~km}$ \\
\hline $\begin{array}{l}\text { How many tourists } \\
\text { per year }\end{array}$ & $10,000+$ & 3.000 & \\
\hline Walking season & January to May and September to December & $\begin{array}{l}\text { April to June and September to } \\
\text { December }\end{array}$ & $\begin{array}{l}\text { April to June and September to } \\
\text { December }\end{array}$ \\
\hline Publications & Many guide books, web pages & $\begin{array}{l}\text { Couple of guide books in several } \\
\text { languages }\end{array}$ & Only one book in English \\
\hline What to see & $\begin{array}{l}\text { It is a reservation area: Landscapes, vernacular } \\
\text { architecture and villages, botanical variety }\end{array}$ & $\begin{array}{l}\text { Ancient cities dating to } 2000 \text { years } \\
\text { ago, landscape views, botanical } \\
\text { variety, vernacular life and also } \\
\text { connecting with modern villages, } \\
\text { wild life }\end{array}$ & $\begin{array}{l}\text { Ancient cities dating to } 2000 \text { years } \\
\text { ago, landscape views, botanical } \\
\text { variety, vernacular life and also } \\
\text { connecting with modern villages, } \\
\text { wild life }\end{array}$ \\
\hline $\begin{array}{l}\text { Signs, labels during } \\
\text { the walkways }\end{array}$ & $\begin{array}{l}\text { No signs but everyone walks with the guides } \\
\text { and every hour a teahouse on the way. }\end{array}$ & $\begin{array}{l}\text { Very detailed signs with colors } \\
\text { every } 10 \text { meters, plates and also } \\
\text { stones done by trekkers }\end{array}$ & $\begin{array}{l}\text { Very detailed signs with colors, } \\
\text { plates and also stones done by } \\
\text { trekkers }\end{array}$ \\
\hline Sponsorship & Governmental action plans inside ACAP & $\begin{array}{l}\text { By Garanti Bank for the signs on the } \\
\text { way }\end{array}$ & $\begin{array}{l}\text { By Garanti Bank for the signs on the } \\
\text { way }\end{array}$ \\
\hline $\begin{array}{l}\text { GPS or new } \\
\text { technologies for } \\
\text { trekkers }\end{array}$ & $\begin{array}{l}\text { An application developed for trekkers and a } \\
\text { lot of web pages }\end{array}$ & A webpage for the trail & $\begin{array}{l}\text { Not well prepared webpage for the } \\
\text { trail }\end{array}$ \\
\hline Accommodation & Teahouse and Lodges & $\begin{array}{l}\text { Local House Pensions, Lodges, } \\
\text { Camping areas }\end{array}$ & $\begin{array}{l}\text { Pensions (very limited) and personal } \\
\text { camping }\end{array}$ \\
\hline $\begin{array}{l}\text { Engaging locals } \\
\text { economically to the } \\
\text { tourism }\end{array}$ & $\begin{array}{l}\text { Very planned way, lot of work for locals such } \\
\text { as porters, markets, guides, market sellers, } \\
\text { pension workers, cafes...etc. }\end{array}$ & $\begin{array}{l}\text { Some of them has café, restaurant } \\
\text { and guesthouses on the way planned } \\
\text { for trekkers. }\end{array}$ & $\begin{array}{l}\text { No preparation for this kind of } \\
\text { tourism because lack of knowledge } \\
\text { and skills }\end{array}$ \\
\hline $\begin{array}{l}\text { Knowledge of the } \\
\text { habitants about } \\
\text { environment }\end{array}$ & $\begin{array}{l}\text { They are all prepared for tourists and they can } \\
\text { inform people in every cases }\end{array}$ & $\begin{array}{l}\text { General knowledge about the area. } \\
\text { They are used to trekkers, don't } \\
\text { surprise and they are generally } \\
\text { prepared. }\end{array}$ & $\begin{array}{l}\text { No knowledge about the trail and } \\
\text { the area nor trekkers. Shy and } \\
\text { curious about tourists }\end{array}$ \\
\hline $\begin{array}{l}\text { Logistical } \\
\text { organization, such } \\
\text { as inscribing } \\
\text { trekkers to a main } \\
\text { system with ID } \\
\text { cards. }\end{array}$ & $\begin{array}{l}\text { Governmental network, inscriptions to the } \\
\text { trekkers community with ID card. Also for } \\
\text { instant health services }\end{array}$ & $\begin{array}{l}\text { Police and habitants know about the } \\
\text { area but no regular process about } \\
\text { inscription }\end{array}$ & $\begin{array}{l}\text { No inscription neither knowledge } \\
\text { about the trail. }\end{array}$ \\
\hline $\begin{array}{l}\text { Variation of } \\
\text { transports }\end{array}$ & $\begin{array}{l}\text { During the way, porters to carry the luggage, } \\
\text { animals for transport, sometimes by bicycles } \\
\text { or horses. }\end{array}$ & Not very much variety of transport. & Not very much variety of transport. \\
\hline $\begin{array}{l}\text { Involvement of } \\
\text { local tour agencies }\end{array}$ & $\begin{array}{l}\text { In Nepal lot of tourism agencies providing } \\
\text { guided tours. You can book online but better } \\
\text { to do it in situ. }\end{array}$ & $\begin{array}{l}\text { Some boutique agencies very slight. } \\
\text { Also some individual guides and } \\
\text { also groups of universities doing this } \\
\text { tour. }\end{array}$ & $\begin{array}{l}\text { No agencies but individual guides } \\
\text { and groups. }\end{array}$ \\
\hline $\begin{array}{l}\text { Local managements } \\
\text { on the way (such as } \\
\text { cafes, teahouses, } \\
\text { guesthouses, first } \\
\text { aid stations etc.) }\end{array}$ & $\begin{array}{l}\text { Every hour there is a small management on } \\
\text { the way with maps and additional equipment } \\
\text { for the trekkers }\end{array}$ & $\begin{array}{l}\text { In some main centers, there are cafes } \\
\text { and services for the trekkers, in the } \\
\text { villages guesthouses }\end{array}$ & $\begin{array}{l}\text { People does not know about the } \\
\text { trail, no preparation for trekkers as } \\
\text { service units. }\end{array}$ \\
\hline
\end{tabular}




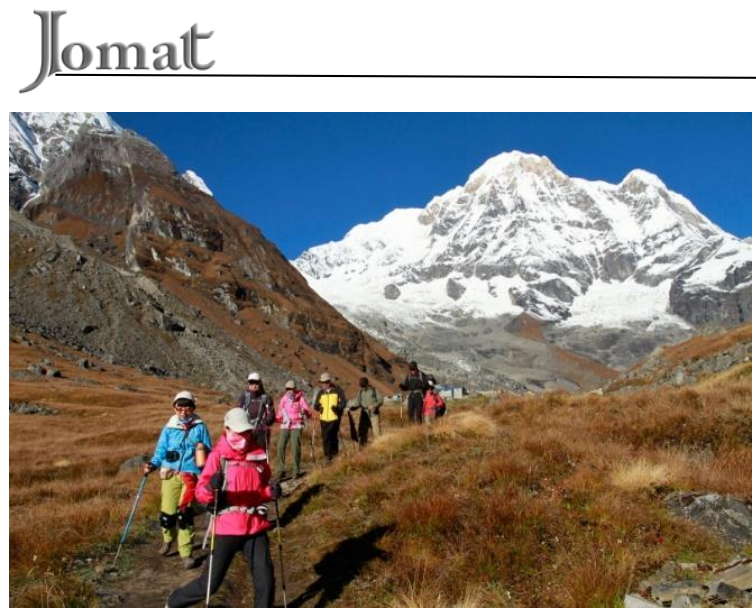

Image 7. Annapurna Circuit and Himalayans. https://www.himalayanwavestrekking.com/nepal/annapurn a-region/item/7-annapurna-circuit-trek

Annapurna Circuit (Image 7) in Nepal (Annapurna Conservation Area Project - ACAP) covers 7.629 square kilometers; can be one of the major examples to the cultural routes. It is one of the best treks, it contains ten mountains that are the highest ones in the world. 115.000 trekkers each year have visited this protected area. The circuit have established in 1986. (Image 8)

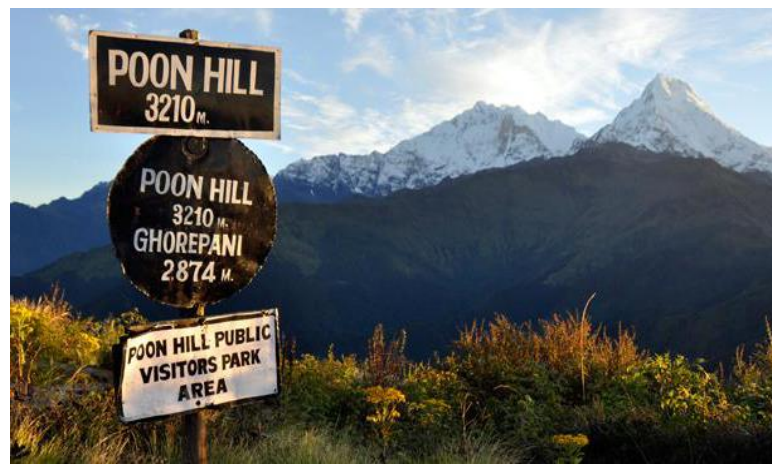

Image 8. Signs during the route

http://parikramatreks.com/assets/createThumb/create_thumb .php?src=/home/parikramatreks/public_html/uploads/packag e/1406709601_ghorepani_poonhill.jpg \&w=800\&h=350

Lycian Route in Turkey investigated and waymarked by Kate Clow with the help of volunteers and Turkish Ministry of Culture in 1999. The road which connects number of ancient cities and paths -dating back to 2000 years ago- is $540 \mathrm{~km}$ and takes 29 days to walk from beginning to ending point. The route is in the southern region of Turkey and it is the first long-distance walking road of the country. (Image 9)

Carian Route that explores the southwest part of Turkey covers $820 \mathrm{~km}$ distance area passing through the ancient ruins of Carian civilization and also, through rural life. The trail has been way marked with GR (Grande Randonnee) in red and white following forest tracks, mule paths and ancient roman roads. The trail opened to trekkers in 2013 and it is a conscious echo of the Lycian Way. (Image 10, 11)

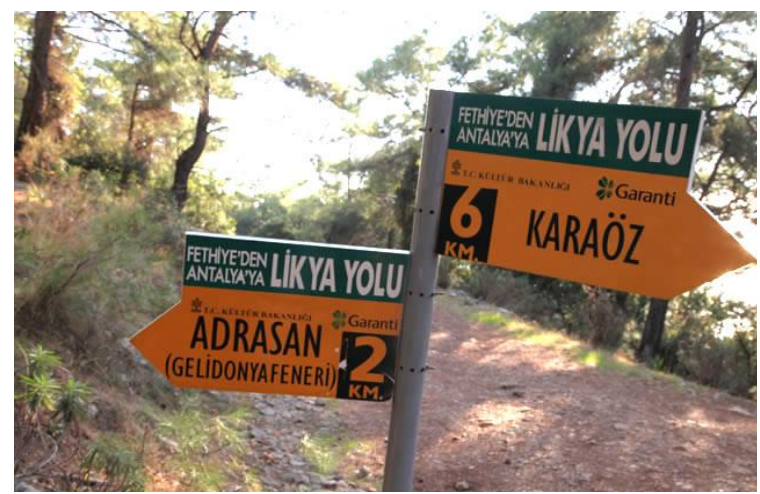

Image 9. Signs along the Lycian Route, (Right) http://lycianwaytrekking.com/images/likya/2.jpg,

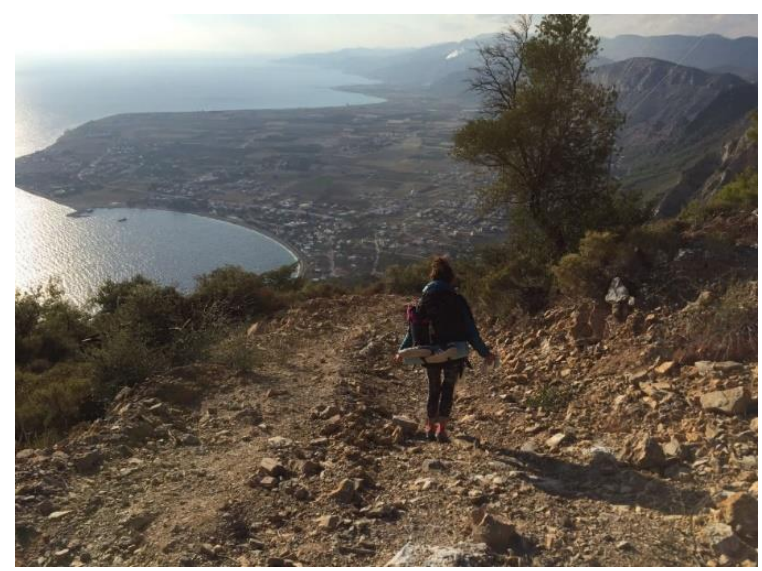

Image 10. Carian Trail, Personal experience

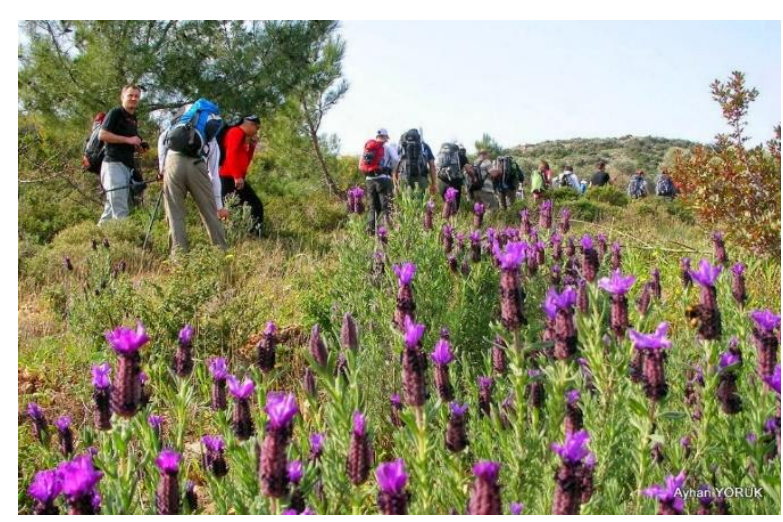

Image 11. Botanical part of Carian Trail http://1.bp.blogspot.com/-

HchO2Nz8aa4/Uz2vouChdxI/AAAAAAAAAYg/DPduTQD 7kAI/s1600/4.Etap-image130.JPG, 


\section{Conventional Tourism Planning vs. Multidisciplinary and Sustainable Tourism Planning}

Tourism plans aim to develop the economy of the countries, usually operate with the business mind for the satisfaction of private sector and economic development of the countries. In the manner of cultural and sustainable tourism planning, as a first step, it should encourage conscious use of natural sources.

"However, the focus of the private sector and tourism planning was naturally oriented toward short-term economic gains, through the construction of facilities which attract foreign visitors. As a result, too little attention was paid to socio-cultural effects on host communities and environmental problems for receiving destinations, which in the long-term, may outweigh the benefits" (Seth, 1985; Jenkins, 1994).

As it is mentioned, with the private sector dominance, tourism planning searches for the short term and quick solutions and economic growth, but this intention brings lack of understanding the identity of the places and in long term unbalanced growth of the areas. In the beginning investors and place owners are happy but after unbalanced and unrestrained growth, this intention fails in many ways, diminishes the character of the places, and the process becomes a low-spending mass tourism with environmental problems. The potentials of the areas should be understood in very detailed scale to be able to operate the planning process with the sustainable mind and preserve the natural and cultural environment.

\subsection{Developing a Multidisciplinary Tourism Planning Approach for the Cultural Routes}

Tourism planning should be flexible and adaptable; to cope with rapidly changing conditions and situations faced by a community (Atach-Rosch, 1984; Choy, 1991). To sum up, the evolution of tourism development planning can be broken down into five stages (Tosun and Jenkins, 1998, p.103):

- "Unplanned tourism development era: during this stage tourism planning is 'uncommon, unpopular and an unwanted idea', and therefore tourism emerges as an unplanned activity.

- Beginning of partly supply-oriented tourism planning stage: this stage is characterized by the construction of basic infrastructure, such as hotels, restaurants, transportation etc.

- Entirely supply-oriented tourism planning stage: at this stage, planning is directed toward the creation of facilities that satisfy increased tourism demand, although it ignores most resulting problems.

- Market or demand-oriented tourism development planning stage: at this stage, tourism planning is focused mainly on greater numbers of tourists and how to satisfy them.

- Contemporary planning approach stage: After the increase in the number of tourist arrivals and the 'careless and myopic tourism

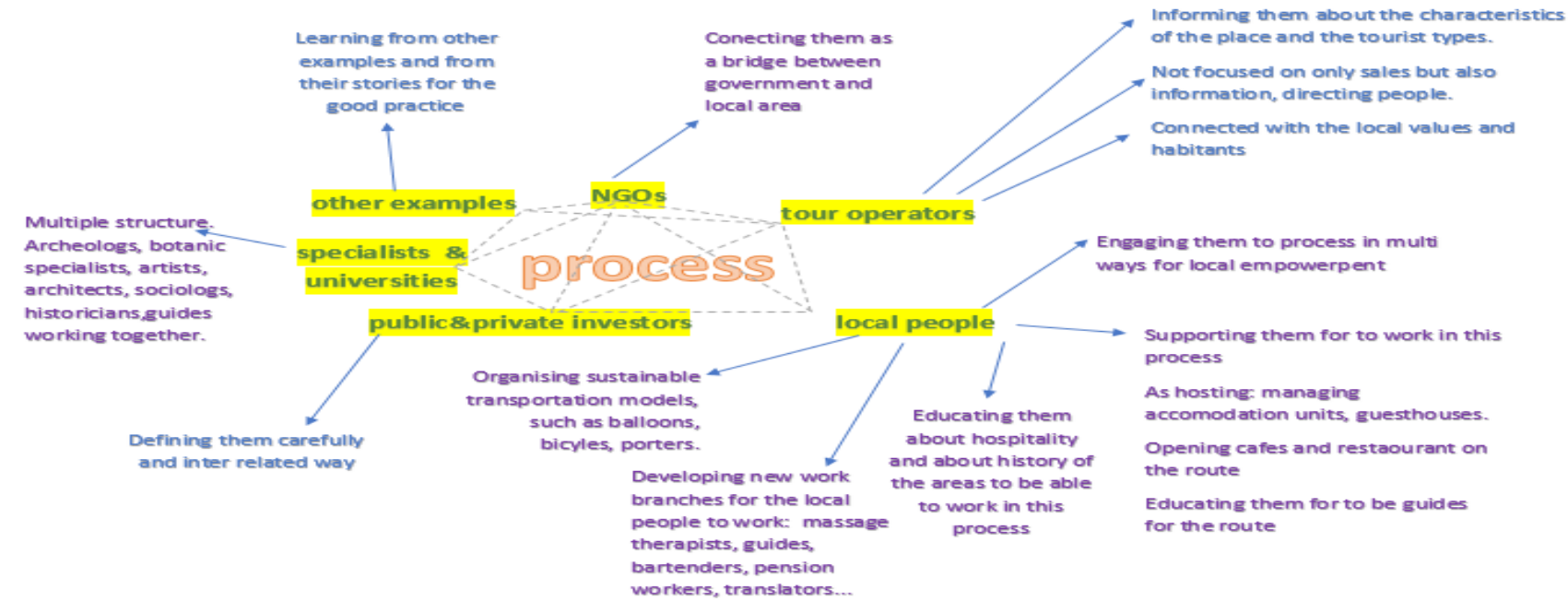

Image 12. Participant roles and linkages during process / Source: Author 
development planning approaches', environmental, socio-cultural and economic problems increase which attracts the attention of developers and planners." This article aims to add another step to these stages mentioned above.

Linkages between the actors of this process is expressed with a diagram in Image 12. It will be beneficial to deconstruct this process to actors and steps after scanning the conventional planning approaches above. By this way, it is aimed to develop and add more values into these steps for the construction process of a multidisciplinary approach and clarifying the linkages in this process. Participants of this process are listed and interpreted below:

- NGOs

- Community Participation

- Specialists and Universities

- Public and Private Investors

- Tour Operators

\section{a) NGOs: Inspiring from Pro-poor tourism for poverty reduction and for rural development and Local Empowerment}

Tourism planning strategies should be able to bring support to hosting local communities. We can learn from pro-poor tourism (PPT) example which is focusing on poverty reduction as a first aim before the environmental issues. This approach can be adapted to poor communities that has the potentiality for cultural routes. PPT can have many actions in the case of cultural rotes such as; educating the unskilled labor, giving them works in the route development process. Some inspiring applications have been done in various sites: Ecuador, Namibia, Nepal and Uganda. In Namibia PPT approach have been implemented to community-based tourism policies and it seems like this action effected on poverty reduction in significant ways. Nacobta (Namibia Communitybased Tourism Association) a non-profit organization is supporting local communities by teaching new skills to small entrepreneurs for to develop tourism and local empowerment. (http://propoortourism.org.uk/) Better decisions can be reached by means of a participative process, even though it is far more difficult. This shift in emphasis does not mean that research and concepts by professional planners are abandoned. Rather, it means that many other constituencies, other than planners, have experiences, opinions and constructive recommendations. Final decisions have a much better chance of being implemented if publics have been involved (Gunn, 1994, p.20).

Stakeholders such as municipalities, NGOs etc. should be involved in the planning and development process for the cultivated tourism of the destinations. Focus should be engaging them to ongoing process as well the future economic linkage. That would need a well-planned educational system to give them new skills and make them exist in the tourism cycle of the area. In Nepal Pokhara region many paragliding teachers come and work here. They also educate young inhabitants for to learn a new skill. These actions should be motivated and organized with more linkages between the NGOs and the community and specialists. In cultural routes local people work as a guide and a porter (Image 13).

\section{b) Community Participation}

"Community involvement in tourism can be viewed from two perspectives: in the benefits of tourism development and in the decision-making process" (McIntosh and Goeldner, 1986; Timothy, 1999; Tosun, 2000). Tourism planning actions should be giving support to the residents in the area for to be involved and participate to the tourism in economic and socio-cultural ways. If the community participation idea is supported with empowerment concept, then it becomes more holistic and training, consciousness raising,

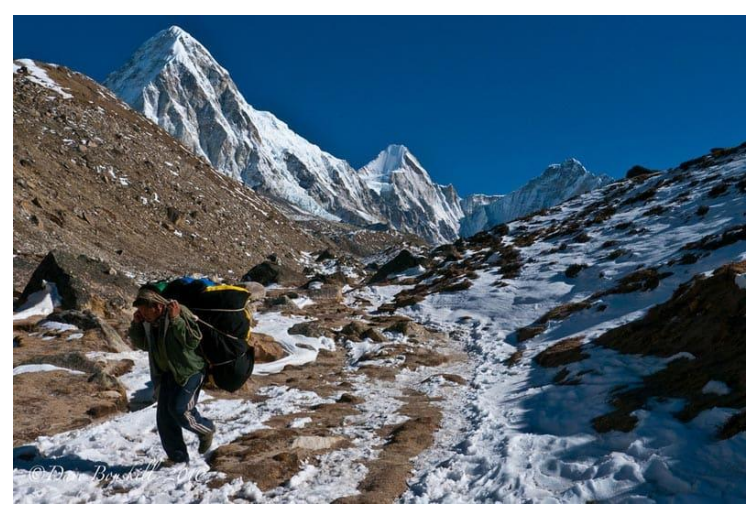

Image 13. Porter carrying heavy load on head https://theplanetd.com/everest-base-camp-trek/ 
education processes can be combined with it. By participation -combined with empowerment and education- societies can be cultivated and this way they will have a wider perspective to shape their future and they can imagine and decide how to live. According to Hall (2000) community participation in tourism planning is "a bottom-up form of planning which emphasizes development in the community rather than development of the community" (p.31).

\section{c) Specialists and Universities}

People from other disciplines should be involved to the planning process of cultural routes such as archaeologists, sociologists, trekkers etc. Universities can be adapted and included in the process

Public and Private Investors: Partnerships in Tourism Planning

Co-operation between the private and the public sector is vital. They should meet in a balanced way with clear understanding of the destinations and needs to be linked with the other actors of the process in double sided and inter-communicative ways.

\section{d) Tour Operators}

Travel agents, outbound and inbound operators and local service providers are included in the tourism market. Travel agents are mostly selling the programs of outbound operators, they are mostly focused on cruise tourism, mass tourism etc. Cultivated tourists does not prefer buying tours from these shops but it will be beneficial informing these agents about the trails. Outbound operators that are specialized on certain areas for a specific activity mostly located in the same areas. Organizing tours, developing tour programs, they have the knowledge of the area. Inbound operators additional to outbound operators they may also have vehicles, lodges etc. as a supportive service. These two operators are crucial on developing cultural routes in a sustainable manner. Local service providers are the ones that are owning a local lodge, pension, local transports, local guides etc. This part of the network is a very important organization that is facing directly with the tourists and travelers. When they feature in main guides they become more accessible. Main actions can be done in this segment are: Introducing these actors with the knowledge of the area, providing support and experience to these actors, providing trainings for local entrepreneurs.

"According to this perception one of the most important international researches on this area the ATLAS research has indicated that the experiences enjoyed most by cultural tourists tend to be those small scale, less visited places that offer a taste of 'local' or 'authentic' culture. Tourists increasingly say that they want to experience local culture, to live like locals and to find out about the real identity of the places they visit" (Richards, 2009).

These basic points should be shared with all actors especially with the ones who are directly in relation with the travelers -for to be able to prevent the enlargement demands of tourism sector. That way we can develop and plan cultural routes in a much more balanced way. It is important to understand that this type of tourism is a way of being, not a way of constant grow. Thus, it cannot be planned with hunger, conscious way of planning approaches and methods are needed in this manner.

\section{Key points for the Multidisciplinary Tourism Planning Approach}

In order to develop a multi-disciplinary perspective and a road map for the Tourism Planning process for Cultural Routes in Turkey, key points -that can support, ease direct this process- are listed below.

\section{Sustainable Transportation Planning and Sustainable Architecture}

"Tourism evolution brings many problems to the local community, i.e. overcrowding, traffic congestion, superstructure, and socio-cultural deterioration. Most of these problems can be attributed to laissez-faire tourism policies and insufficient planning" (Edgell, 1990). Therefore, sustainable ways of transportation and infrastructure are needed. In the ways of building in these areas, vernacular typologies, local 
architecture, local materials should be evaluated with the natural resources, landscape and botanical inputs and if it is necessary the new units should be designed with this attention. Variation of sustainable, low carbon transports should be organized such as using bicycles, balloons, electronic bicycles and also in mountain villages help of the strong animals as they are using in Himalayans.

\section{Learning from Other Examples}

"Tourism planners should learn from mistakes made elsewhere and realize that the planning process is not a static but a continuous process which has to integrate exogenous changes and additional information" (de Kadt, 1979; BaudBovy, 1982; Gunn, 1994; Hall, 2000). "Therefore, tourism planning should be flexible and adaptable; to cope with rapidly changing conditions and situations faced by a community" (Atach-Rosch, 1984; Choy, 1991). Thus, interchanging knowledge and learning from others is beneficial for the good practice of design and planning.

\section{Conclusion}

Although tourism is being practiced since many years, evolving with the demands of main economic system and places are being consumed by most of the cultural tendencies; still there is another way of living -and traveling- is being practiced. Every year many people are getting more conscious about how they live, how they eat and how they exist. These tendencies reflect to the culture of the communities, to their consuming types as well as their tourism typologies. Cultural routes are just like nodes of experience, culture and dynamism. This way of tourism can be a way of educating, empowering people, creating interchanges in between each other, through a balanced way. Cultural routes need to be seen and interpreted with these conscious lenses. These areas need to be planned with a wise and mature touch and awareness to nature, to inhabitants and to culture -it cannot happen by pushing them to the regular tourism market strategies for to transform their local culture and habits, or by adapting new "fake" way of authenticity for the mass development of the area.

The paper starts by describing cultural tourism with the purpose of underlying the culture and its relationship with the society and tourism. On the other hand, this issue is crucial to be able to adapt a new way of tourism planning. Therefore, after scanning conventional tourism planning approaches, paper aims to create a productive linkage between cultural routes and multidisciplinary development. Diagrams express the main dynamics of this process in simple way. Blending of author's personal experiences on these three routes as a cultural tourist and the literature review that has been done, tries to open a new lens to this subject, in order to develop a holistic approach.

Paper aims to unfold the supporting ideas of multidisciplinary perspectives to planning of Cultural Routes such as; engaging locals to the process more, participation of inhabitants, organizing area related science committee and professionals to the development process and educating people and tourism suppliers about the nature of contented and tranquil development. We should not only focus on reducing the local impacts of tourism in the long term, but we should also be seeking alternative, functional, simple ways of poverty reduction and community participation. Cultural tourism and cultural routes are holding an important value for the local empowerment and Turkey has several routes all around the country and these areas have important potential waiting to be seen and developed with multi-disciplinary manners and conscious lenses.

\section{References}

Atach-Rosch, I. (1984). Public Planning for Tourism: A General Method for Establishing Economic, Environmental, Social and Administrative Criteria. $\mathrm{PhD}$ thesis. Washington, University of Washington.

Baud-Bovy, M. (1982). New concepts in planning for tourism and recreation. Tourism Management, 3(4), 308-313.

Berki, M. - Csapó, J. (2008). The Geographical Basis for the Development of Thematic Routes. In D.

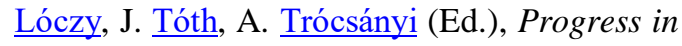
Geography in the European Capital of Culture 2010. University of Geography, University of Pécs. Geographica Pannonica, Nova 3(1), 161173.

Choy, D.J.L. (1991). Tourism planning: The case for 'market failure'. Tourism Management, 12(4), 26-31. 
Cultural Routes Society, Lycian Way. Retrieved 01.07.2019 from http://cultureroutesinturkey. com/the-lycian-way/.

De Kadt, E. (Ed). (1979). Tourism: Passport to Development? Oxford: Oxford University Press.

Hall, C.M. (2000). Tourism Planning: Policies, Processes and Relationships. Essex: Prentice Hall.

ICOMOS Charter for Cultural Tourism (1997). Retrieved 01.07.2019 from https://www.icomos. org/charters/tourism_e.pdf.

Jenkins, C. L. (1994). Tourism in developing countries: the privatisation issue. Tourism: The State of the Art, John Wiley \& Sons, Chichester, UK, 3-9.

McIntosh, R.W., \& Goeldner, G.R. (1986). Tourism: Principles, Practices, Philosophies. $5^{\text {th }}$ ed. New York: Wiley.

McKercher, B., \& Du Cros, H. (2002) Cultural Tourism: The Partnership Between Tourism and Cultural Heritage Management. Haworth Press, Binghamton.

Paschinger, E. (2007) Authenticity, interpretation and the issue of demand: How product development at world heritage sites can encourage sustainable management. MA Thesis, IMC University of Applied Sciences Krems.

Pro-poor Tourism. Retrieved 01.07.2019 from http://propoortourism.org.uk/.

Puczkó, L. \& Rátz, T. (2007). Trailing Goethe, Humbert and Ulysses Tourism: Cultural Routes in Tourism. In G. Richards (Ed.), Cultural Tourism: Global and Local Perspectives, Haworth Press, New York.
Edgell, D.L. (1990). International Tourism Policy. New York: Van Nostrand Reinhold.

Gunn, C.A. (1994). Tourism Planning: Basics, Concepts, Cases. $3^{\text {rd }}$ ed. Washington: Taylor \& Frances.

Richards, G. (2003) What is Cultural Tourism? In A. van Maaren (Ed.), Erfgoed voor Toerisme. Nationaal Contact Monumenten.

Richards, G. (2009). Tourism development trajectories -From culture to creativity? Encontros Cientificos-Tourism \& Management Studies, n.6, 9-15. Retrieved 14.07.2017 from. http://www.tramresearch.com/atlas/APC\%20Paper\%20Greg\%2 $\underline{\text { ORichards.PDF }}$

Roshan Cultural Heritage Institute. Retrieved 01.07.2019 from http://www.roshaninstitute.org/474551.

Seth, P.N. (1985). Successful Tourism Management. New Delhi, Stirling.

Timothy, D.J. (1999). Participatory planning. A view of tourism in Indonesia. Annals of Tourism Research. 26(2), 371-391.

Tosun, C. (2000). Limits to community participation in the tourism development process in developing countries. Tourism Management. 21(3), 413633

Tosun, C., \& Jenkins, C.L. (1998). The evolution of tourism planning in third world countries: A critique. Progress in Tourism and Hospitality Research. 4(2), 101-114.

Tylor, E. (1871). Primitive Culture. Cambridge University Press.

WTO Report. (2012). Retrieved 01.07.2019 from http://cf.cdn.unwto.org/sites/all/files/pdf/annual report_2012.pdf. 